\title{
Dynamics and ecology of an Indo-Pacific conch, Conomurex persicus (Mollusca: Gastropoda) in southeastern Turkey
}

\author{
Erhan Mutlu ${ }^{1} \&$ Mehmet Betil Ergev ${ }^{2}$ \\ 1 Institute of Marine Sciences, Middle East Technical University POB 28, Erdemli, 33731, Mersin, Turkey, Fax: +90 \\ 324 5212327; mutlu@ims.metu.edu.tr \\ 2 Middle East Technical University, Faculty of Arts and Sciences, Department of Biology, Ankara, Turkey.
}

\author{
Received 27-V-2005. Corrected 02-VIII-2005. Accepted 09-IX-2005.
}

\begin{abstract}
Conomurex persicus, one of the tropical conchs, has been introduced to one of the subtropical regions, the northeastern Mediterranean Sea, and invaded sandy bottoms between 1 and $10 \mathrm{~m}$ deep. Population dynamics were studied from specimens collected with a standard dredge $(60 \times 15 \mathrm{~cm}$ mouth opening, $0.5 \times 0.5 \mathrm{~cm}$ eye opening of net). Samples of $C$. persicus were collected monthly along the 5 and $10 \mathrm{~m}$ depth contours off Erdemli, Mersin, Turkey, in February and May 2000. Intra-annual density depended on salinity levels, while inter-annual density was correlated with bottom water temperature. Specimens underwent spring emergences and winter burial and sheltering (disappearance). Emergence took place in March when temperatures rose and the disappearance occurred in October-November when temperatures dropped. Adults live at $10 \mathrm{~m}$, juveniles are recruited at a $5 \mathrm{~m}$ depth. Recruitment began in April and continued for the next 6 months. In contrast to shell width or shell lip thickness, shell length was not a convenient index for estimation of growth parameters. Annual production and mortality were calculated to be $7.86 \mathrm{~g} \mathrm{~m}^{-2}$ and $3.80 \mathrm{~g} \mathrm{~m}^{-2}$, respectively, in April-November. Rev. Biol. Trop. 54(1): 117-129. Epub 2006 Mar 31.
\end{abstract}

Key words: Conch, distribution, ecology, population dynamics, Mediterranean Sea.

The northeastern Mediterranean, like other parts of the Mediterranean Sea, has provided both temporary and permanent habitats for exotic marine species since the beginning of interoceanic shipping and particularly enhanced by the connection to the Indo-Pacific regions opened via the Suez Canal. Many exotic species have been recorded in the Mediterranean Sea (CIESM, Nicolay and Manoja 1983, Galil 2000, Ergev 2002, Mutlu 2002, Gofas and Zenetos 2003). One exotic gastropod species (Conomurex persicus Swainson, 1821), was first sighted in Mersin Bay, Turkey, in 1978, and then in rapid succession off Israel, Rhodes, Cyprus and Lebanon (Nicolay and Manoja 1983). Conomurex persicus in the eastern Mediterranean is invasive and this invasion was an example of a 'lessepsian' introduction (Gofas and Zenetos
2003). Previously, no detailed studies on the ecology, population dynamics or biology of subspecies of the $C$. persicus have been made, even though $C$. persicus is common in the Persian Gulf. The species produces as much as $58 \%$ of the total community respiration and $75 \%-93 \%$ of the total biomass along the Syrian coasts (CIESM). Although C. persicus is currently only a widely consumed species in Israel, it has a potential for commercial export throughout the Mediteranean Sea (CIESM). All Strombus species are herbivorous, feeding on algae. Given a density of tens of specimens per $\mathrm{m}^{2}, C$. persicus should also consume a large amount of fraction of the algae. One of the two dominating algal species in this region is Jania rubens (Lamouroux, 1812) which is often found in the stomach of juveniles and subadults of $C$. persicus (Mutlu 2004). It is 
expected that as Sandy bottom dwellers, adults of the species feed on detritus and plankton. They are most active at night (CIESM), migrating to the rock shores (harbor) of the study area (Fig. 1). Long-term observations of the authors in the study region showed a decrease in the density of $J$. rubens of a magnitude consistent with the potential grazing impact of the gastropod (Mutlu 2004). This alga normally supports a rich fauna of native animals and with the decrease of its density; there could be a drop in the abundance and number of species supported by this alga.

Due to the potential for future impacts on the native ecosystem, we have studied the background density distributions, population dynamics, biometry, and growth parameters of $C$. persicus. This conch could play a crucial role in ecosystem, depending on its density within the community, along a section of the southeastern Mediterranean coast of Turkey. This is the first study on the population dynamics of the Erythrean invasive species, C. persicus in the Mediterranean Sea.

\section{MATERIAL AND METHODS}

Samples of $C$. persicus individuals were collected monthly along the 5 and $10 \mathrm{~m}$ depth contours off Erdemli, Mersin (Fig. 1) from June 2000 to November 2001 and then seasonally between February and July 2002. The samples collected at $10 \mathrm{~m}$ in February and May

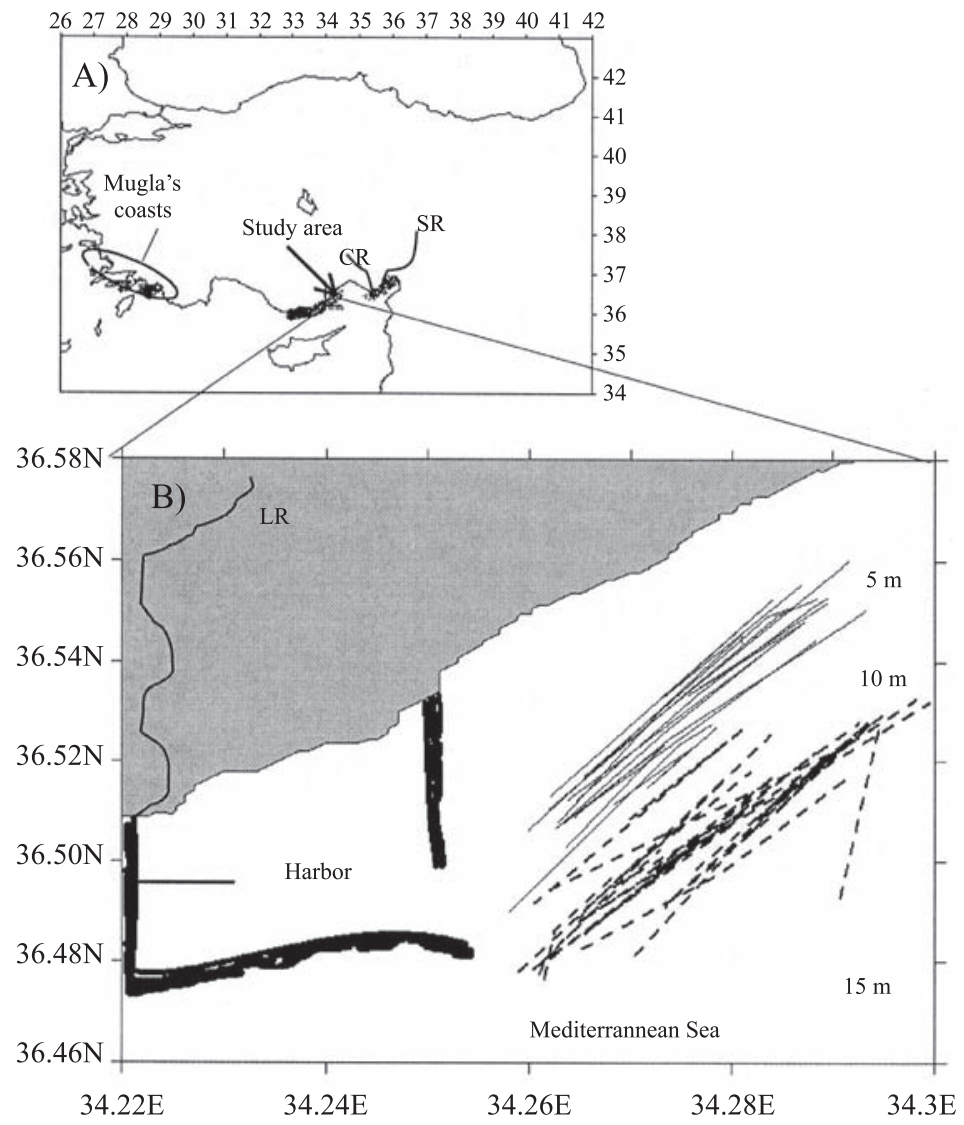

Fig. 1. Locations where $C$. persicus was observed along the coastal band (black spots) and the study area (A) (CR: Ceyhan River and SR: Seyhan River) where the dredge was deployed and line stations at 5 (solid lines) and $10 \mathrm{~m}$ (dashed lines) depth contours and moles of the Institute of Marine Sciences' harbor (B) (LR: Lamas River). 
2000 (Ergev 2002) were considered for the present study. The bottom sediments at these depths consist of sand. Conomurex persicus specimens were not found at greater depths, where mud predominates.

The samples were collected with a standard dredge $(60 \times 15 \mathrm{~cm}$ mouth opening, $0.5 \times$ $0.5 \mathrm{~cm}$ eye opening of net) deployed from $\underline{\mathrm{R} / \mathrm{V}}$ 'Erdemli'. The 15 minute dredging tows were conducted at 2 knots. Water temperature, salinity and density were measured using a SeaBird Oceanographic probe. Abundance (ind $\mathrm{m}^{-2}$ ) was standardized over the sampling distance measured by GPS. Several SCUBA dives were conducted to investigate where the individuals had gone around the study area in winter when a few or no individuals of the species were collected with the dredge.

On board, samples with total number of individuals higher than about 500 inds were sub-sampled, with 3-5 jars each containing 7090 randomly taken specimens preserved, and the rest of these samples were only counted.

In the laboratory, shell lengths and widths of the specimens were measured with a micrometer to the nearest $0.01 \mathrm{~mm}$, and weight to $0.0001 \mathrm{~g}$. Efficiency of the sub-sampling method from just big net tows was statistically tested involving individual length and weight measurements into dispersion index, I (Anon 1991). The I values showed that the sub-sampling was efficient.

Conomurex persicus can be divided into 2 stages: subadult and adult. The adult shells are generally thickened and possess a U-shaped notch on the edge of the lip near the anterior end. Monthly length-frequency (L/F) distributions were sorted into $0.3 \mathrm{~cm}$ length classes as well as shell width into $0.075 \mathrm{~cm}$, and wet weight into $2 \mathrm{~g}$. Annual growth rate $(\mathrm{K})$, asymptotic length $\left(\mathrm{L}_{\infty}\right)$, winter point (WP; in the seasonalized VBGF, von Bertalanffy Growth Function, time of the year when growth rate is slowest) and amplitude of seasonal growth oscillation in the VBGF (C) were estimated using a mathematical models, ELEFAN I (Electronic Length Frequency Analysis, Gayanilo and Pauly 2001). The function was solved for every stock and stage at 5, 10 and 5+10 m depths for year 2001 due to interannual difference observed for $\mathrm{L} / \mathrm{F}$ distribution. Growth curve of $C$. persicus was fitted by the "seasonalized VBGF (Gayanilo and Pauly 2001). The subadults recruited to the stock were involved into the growth function.

\section{RESULTS}

Physical properties (temperature, salinity and density) of coastal waters in the study area are variable, depending on a number of circumstances as a consequence of atmospheric events. Regionally, significant amount of rainfall occurred in December-February and April-May in the study area (Fig. 2A). Inflows from the Lamas and Erdemli rivers (LM, Fig. 2B) to the area increased substantially in spring months. In additional to direct interaction of coastal and open waters, the inflow of the large Seyhan and Ceyhan rivers (SR and CR, Fig. 2A) into Mersin and Iskenderun Bays further influenced seasonal variation in the area, connected by the meandering currents along the southern coast Turkey. The river outflows had minor but significant effects on the sea salinity and temperature, and in turn restricted distribution of $C$. persicus due to the nearly isothermal profiles over much of the year. Temperature of the sea varied between 16 and $\sim 30^{\circ} \mathrm{C}$ (Fig. 2B). The temperature was below $20^{\circ} \mathrm{C}$ during November-May and then rose abruptly to $\sim 30^{\circ} \mathrm{C}$ in August. There could occasionally be difference in temperatures at surface, $5 \mathrm{~m}$ and $10 \mathrm{~m}$ depths: the temperature was $\sim 4^{\circ} \mathrm{C}$ warmer at the surface than at $10 \mathrm{~m}$ in July/August in 2002 and 2 degrees warmer in May 2000 (Fig. 2B). Typically salinity of the area was about 39 psu, which was observed all the period of July 2000 to December 2001. Before and after the period, stratification in the salinity profile occurred during high to riverine inputs and precipitation events when less saline waters were observed throughout the water column (Fig. 2C).

Superficial sediment of the study area was composed mainly of sand; gravel and 

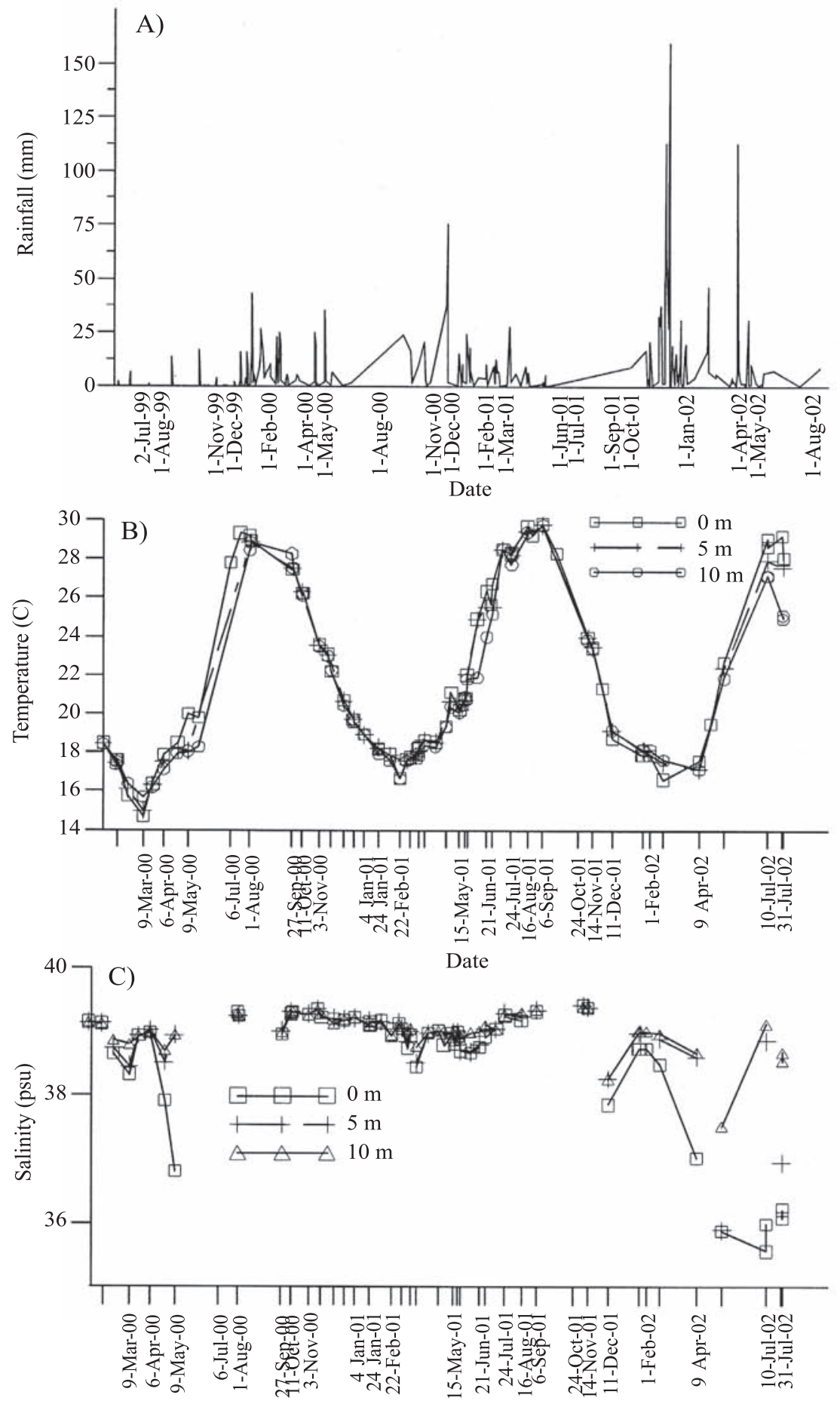

Date

Fig. 2. Daily local rainfall (A, mm), and sea surface and near bottom temperature $\left(B,{ }^{\circ} \mathrm{C}\right)$, and salinity $(\mathrm{C}$, psu) in the study area. 
mud sediment contributed less than $1 \%$ of the composition. At deeper areas (i.e. at $25 \mathrm{~m}$ ), mud content in the sediment increased and sand content tended to decline. Inorganic carbon (IngC) and total carbonate (TC) in the sediment varied between 30 and 40 percent in the zone. Total organic carbon (TOC) increased from 0.1 to $0.40 \%$ with increased bottom depth.

Depth distribution of $C$. persicus was restricted to regions from 1 to $12 \mathrm{~m}$ deep along the southeastern coast of Turkey (Fig. 1A). The sediment within the depth range $(0-10 \mathrm{~m})$ was composed of slightly gravelly sand whereas deeper sediment had higher mud content. Stock of $C$. persicus at $5 \mathrm{~m}$ depth significantly differed from that at $10 \mathrm{~m}$ in terms of morphological characters (mean shell length and individual wet weight) (Table 1), with mean values of both parameters significantly smaller at $5 \mathrm{~m}$ than those at $10 \mathrm{~m}$. There was no significant difference in abundances (ind $\mathrm{m}^{-2}$ ) and biomasses $\left(\mathrm{g} \mathrm{m}^{-2}\right)$ between $5 \mathrm{~m}$ and $10 \mathrm{~m}$ (Table 1). Male specimens comprised $\sim 40 \%$ of the stock $(n=372)$.

TABLE 1

Results of Mann-Whitney $U$ test for difference of biological measurements of $\mathrm{C}$. persicus between 5 and $10 \mathrm{~m}$ depths

Variables

Smallest U p level n

Total number of individuals (ind dredge ${ }^{-1}$ )

$212.5 \quad 0.49 \quad 21$

Abundance (ind $\mathrm{m}^{-2}$ )

$213 \quad 0.50 \quad 21$

Individual wet weight $(\mathrm{g})^{*}$

$61 \quad 0.00 \quad 21$

Biomass $\left(\mathrm{g} \mathrm{m}^{-2}\right)$

Mean shell length $(\mathrm{cm})^{*}$

75

0.00

U: Mann-Whitney U statistic, p level: significance level, $\mathrm{n}$ : sample size (number of months)

Bold number; significantly different,

Italic number is the smallest $\mathrm{U}$ value that belonged to $5 \mathrm{~m}$ depth; other that to $10 \mathrm{~m}$ depth,

* Significantly different variables as well as Wilcoxon matched pairs test applied.
Interannual biomass and abundance: Conomurex persicus populations varied greatly in density between 2000 and 2001. Low biomass (1-5 $\left.\mathrm{g} \mathrm{m}^{-2}\right)$ and abundance (0.05-0.22 ind $\mathrm{m}^{-2}$ ) were observed in summer 2000 (July, August) with much higher biomass (20-45 $\left.\mathrm{g} \mathrm{m}^{-2}\right)$ and abundance $\left(0.8-1.8\right.$ ind $\left.\mathrm{m}^{-2}\right)$ in summer 2001 (June to August) (20-60 $\mathrm{g} \mathrm{m}^{-2}$ ) (Fig. 3 ). In the summer 2002 (July) then were no specimens at $10 \mathrm{~m}$ whereas they were found at $5 \mathrm{~m}\left(2\right.$ ind $\mathrm{m}^{-2}$ and $\left.60 \mathrm{~g} \mathrm{~m}^{-2}\right)$. Temperature at $5 \mathrm{~m}$ was $4^{\circ} \mathrm{C}$ higher than that $\left(\sim 24^{\circ} \mathrm{C}\right)$ at $10 \mathrm{~m}$ (Fig. 2B) during the summer 2002. Near bottom water temperature was lower and more saline compared to surface water during the late spring and summer (May to July) of 2000 and 2002 (Fig. 2). Furthermore, biomass and abundance peaks observed during the spring (May) of 2000, 2001 and autumn (October, November) 2000 did not reoccur in the following years (Fig. 3). During spring and autumn (2000-2002) the water column was homogenous in terms of temperature while surface water was less saline and dense compared to the near bottom waters. This wasn't true for the spring and autumn periods in 2001. Density of C. persicus in summer and autumn 2001 was higher than in the previous year (Fig. 3).

Depth abundance and biomass: The population of $C$. persicus varied in density with depth; at $5 \mathrm{~m}$ its density increased winter to summer, when the sea surface and near bottom temperature increased from $18^{\circ} \mathrm{C}$ to $30^{\circ} \mathrm{C}$. The density declined with decreasing temperatures $\left(22^{\circ} \mathrm{C}\right)$ in autumn. At $10 \mathrm{~m}$, the density increased abruptly in spring and declined in summer with the increased temperature $\left(30^{\circ} \mathrm{C}\right)$. In the study area (pooled data), the density increased ten-fold from winter to spring, remained unchanged in summer, and then decreased by half in autumn (Fig. 2B and Table 2). Regarding the sampling depth density, C. persicus showed no difference between $5 \mathrm{~m}$ and $10 \mathrm{~m}$ during months of winter and summer. Spring and autumn were characterized by peaks in the density averaged based on both depths. At the end of this period, the density 


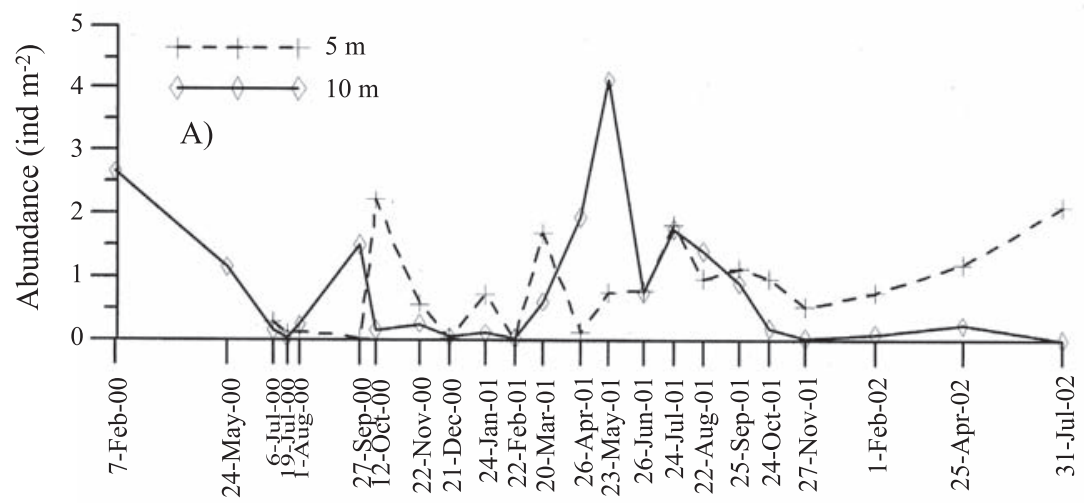

Date

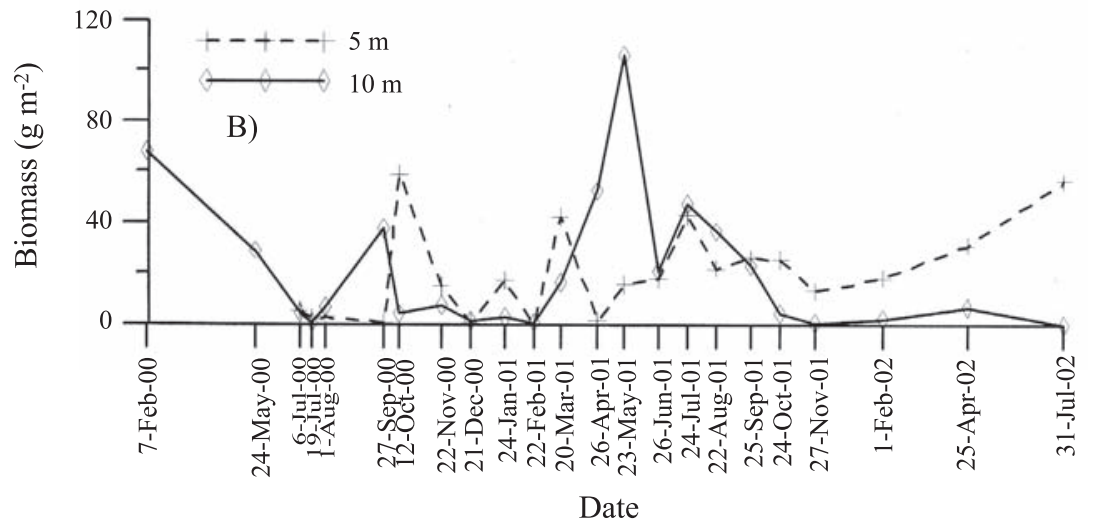

Fig. 3. Monthly abundance (ind. $\mathrm{m}^{-2}$ ) of C. persicus individuals collected from February 2000 to July 2002.

peaked at $5 \mathrm{~m}$ but dipped at $10 \mathrm{~m}$. After wintering the individuals were aggregated first at $5 \mathrm{~m}$ (March), then started to appear at $10 \mathrm{~m}$ by April and reached their highest density in May at $10 \mathrm{~m}$ (Fig. 3). Visual inspections by divers determined that $C$. persicus individuals were about to be buried, or semi-buried in the very shallow water (1-2 m depth) and most of the individuals left the study area, and accumulated around underwater rocks near the IMS-harbor during winter.

Stages, morphometric characters and size composition: Frequency of occurrence of $C$. persicus stages (subadult and adult) for each sample was given in Fig. 4. The subadults were observed only at $5 \mathrm{~m}$ depth, and adult specimens were found only at $10 \mathrm{~m}$. Presence and predominance of the subadults varied depending on the period absent in winter, early spring and late autumn. Dominance of the subadults was more pronounced in spring $(>20 \%)$ than that in summer $(<20 \%)$.

Shell width, length and wet weight of the juveniles ranged from 1.1 to $3.1 \mathrm{~cm}$ (mean: $2.1 \mathrm{~cm}, \mathrm{n}=128$ ), from 2.4 to $5.5 \mathrm{~cm}$ (mean: $4.0 \mathrm{~cm}, \mathrm{n}=128)$, and from 1.4 to $12.1 \mathrm{~g}(8.2$ $\mathrm{g}, \mathrm{n}=128)$, respectively whereas those of the adults varied between 2.1 and $3.9 \mathrm{~cm}(3.0 \mathrm{~cm}$, $\mathrm{n}=1504)$, between 3.1 and $6.1 \mathrm{~cm}(5.2 \mathrm{~cm}$,

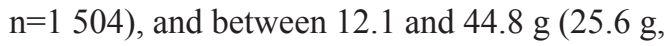
$\mathrm{n}=1$ 504), respectively during July 2000-July 2002. Biometrical values of the male specimens were slightly smaller than those of the females (Table 3). Only total weight (W) of the females was significantly heavier than that of the males (2.27, Parametric t-student test, $\mathrm{n}=138, \mathrm{p}=0.025$ ). 
TABLE 2

Seasonal mean abundance (ind $\mathrm{m}^{-2}$ ), and biomass $\left(\mathrm{g} \mathrm{m}^{-2}\right)$ of C. persicus at 5, $10 \mathrm{~m}$ depths and in the study area in year 2001

$\begin{array}{cc}\begin{array}{c}\text { Abundance } \\ \left.\text { (ind } \mathrm{m}^{-2}\right)\end{array} & \begin{array}{c}\text { Biomass } \\ \left(\mathrm{g} \mathrm{m}^{-2}\right)\end{array}\end{array}$

Study area

\begin{tabular}{lll} 
Winter & 0.15 & 3.99 \\
Spring & 1.33 & 30.95 \\
Summer & 1.24 & 31.03 \\
Autumn & 0.61 & 15.57 \\
\multicolumn{1}{c}{ At $5 \mathrm{~m}$} & & \\
Winter & 0.24 & 5.86 \\
Spring & 0.84 & 19.64 \\
Summer & 1.18 & 27.50 \\
Autumn & 0.87 & 21.48 \\
\multicolumn{1}{c}{ At $10 \mathrm{~m}$} & & \\
Winter & 0.05 & 1.65 \\
Spring & 2.22 & 58.24 \\
Summer & 1.30 & 34.87 \\
Autumn & 0.36 & 9.37
\end{tabular}

The length-weight relationship was positive with a negative allometric growth. The adults' growth diminished after a certain length $\left(\mathrm{L}_{\infty} \sim 5.7 \mathrm{~cm}\right.$, see growth parameter analysis for details) and thereafter showed increase only in width. Therefore, a curvilinear multi-regression was an appropriate model to characterize length-width-weight relationship of $C$. persicus (Fig. 5). Accordingly, the multiple relationships were found to be statistically more significant than the two-variable relationship (Fig. 5). However, the multiple-regression model is inconvenient for length-width-weight relationship of the subadults. This suggested also that the juveniles and subadults increased mostly in length. Shell thickness of C. persicus subadults up to $5.1 \mathrm{~cm}$ in length and $3.2 \mathrm{~cm}$ in width was less than $1 \mathrm{~mm}$. Adults' lip-thickness varied between $2.5 \mathrm{~mm}$ and 5 $\mathrm{mm}$. Tissue wet weight-shell width-length of C. persicus was characterized with an equation of: $\log _{10}\left(\mathrm{~W}_{\text {Tissue }}, \mathrm{g}\right)=-1.081+0.93 \log _{10}(\mathrm{Wd}$, $\mathrm{cm})+1.76 \log _{10}(\mathrm{~L}, \mathrm{~cm})$. (Regression analysis, $\mathrm{r}=0.70, \mathrm{p}=0.0000, \mathrm{n}=134)$.

TABLE 3

Sex-dependent biometrical statistics of C. persicus at $5 \mathrm{~m}$ and $10 \mathrm{~m}$ depth

At 5 m (July 2002)

$\mathrm{Wd}(\mathrm{cm}) \quad \mathrm{L}(\mathrm{cm}) \quad \mathrm{W}(\mathrm{g}) \quad \mathrm{W}_{\text {tissue }}(\mathrm{g}) \quad \mathrm{Wd}(\mathrm{cm}) \quad \mathrm{L}(\mathrm{cm}) \quad \mathrm{W}(\mathrm{g}) \quad \mathrm{W}_{\text {tissue }}(\mathrm{g})$

Female

$\begin{array}{ccccccccc}\text { Minimum } & 2.335 & 4.115 & 10.3945 & 2.1759 & 2.385 & 4.465 & 13.4670 & 2.1203 \\ \text { Mean } & 3.116 & 5.250 & 26.7407 & 4.3170 & 3.045 & 5.248 & 25.74900 & 4.4569 \\ \text { Maximum } & 3.520 & 5.715 & 36.8449 & 7.2436 & 3.395 & 5.980 & 37.3560 & 6.2871 \\ \text { Male } & & & & & & & & \\ \text { Minimum } & 2.245 & 4.720 & 15.6732 & 2.7663 & 2.685 & 4.625 & 18.2608 & 2.8839 \\ \text { Mean } & 2.971 & 5.138 & 23.3839 & 4.2433 & 3.084 & 5.249 & 25.1058 & 4.5863 \\ \text { Maximum } & 3.365 & 5.785 & 32.7064 & 5.5741 & 3.385 & 5.645 & 31.8581 & 5.8485\end{array}$

Wd: shell width,

L: shell length,

$\mathrm{W}$ : shell + tissue weight,

$\mathrm{W}_{\text {tissue }}$ : weight of tissue. 

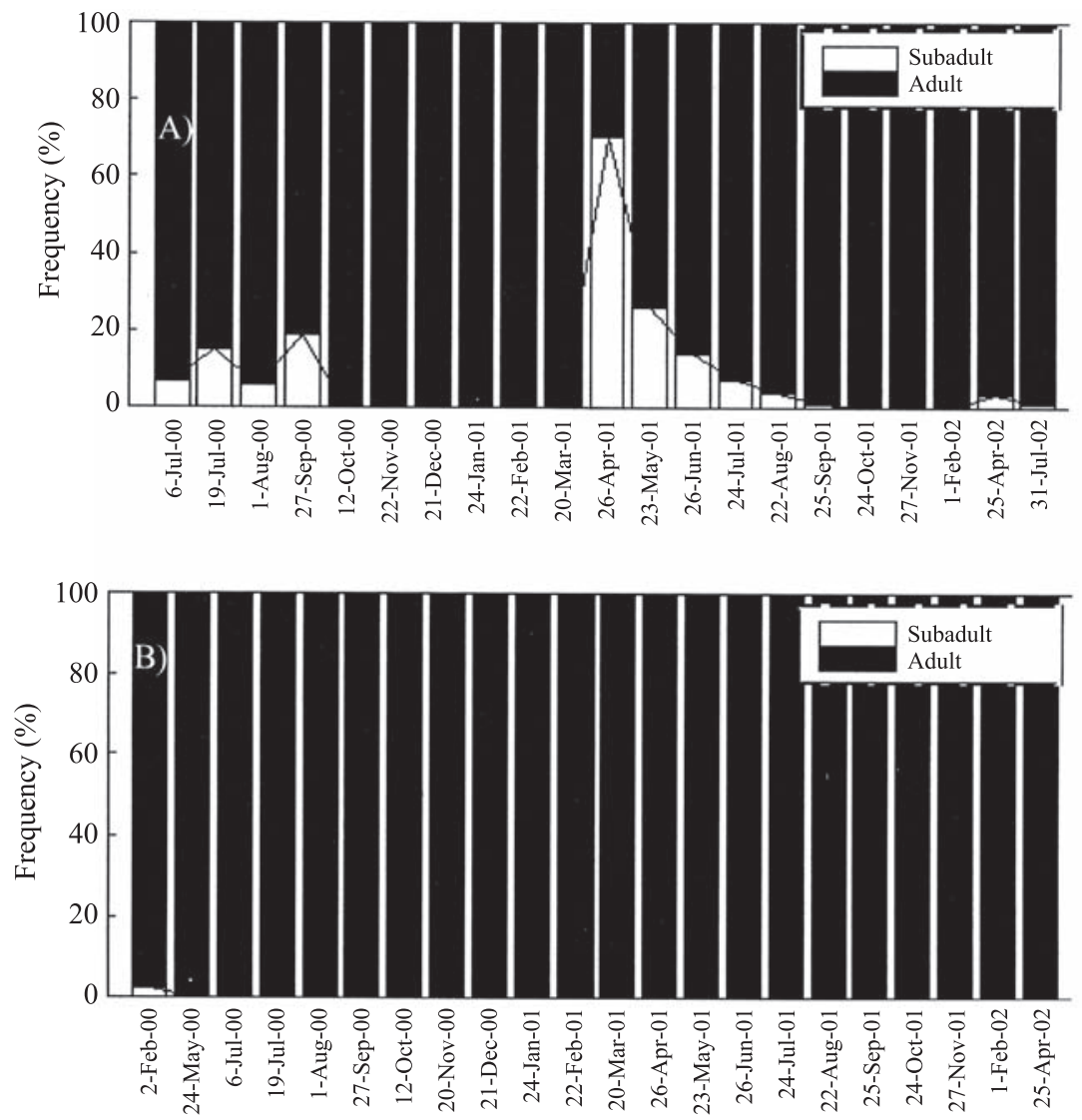

Fig. 4. Monthly compositions of subadult and adult stages of C. persicus individuals collected at $5 \mathrm{~m}$ (A), and $10 \mathrm{~m}$ (B).

Growth parameters: Table 4 and Fig. 6 show an application of ELEFAN I to shell length (L) and width (Wd) of C. persicus. This growth curve in the length of its subadults was a von Bertalanfyy growth curve because $\Delta \mathrm{L} / \Delta \mathrm{t}$ of the subadults decreases linearly with the sampling period as a function of the aging of the individuals. The growth curve estimated upon $\mathrm{L}$ of adults and $\mathrm{Wd}$ of the specimens was not clearly a von Bertelanffy growth curve because $\Delta \mathrm{L} / \Delta \mathrm{t}$ of the adults and $\Delta \mathrm{Wd} / \Delta \mathrm{t}$ did not decrease linearly with age. So, ELEFAN I worked with the "seasonalized von Bertalanffy growth equation". This means that this term produced seasonal oscillations of the growth rate, by changing $t_{0}$ during the year.

Asymptotic lengths $\left(\mathrm{L}_{\infty}\right)$ varied between 5.7 and $6.0 \mathrm{~cm}$ depending on the sampling depths and stages of the species. In contrast to annual growth rate $(\mathrm{K})$, the $\mathrm{L}_{\infty}$ of the subadults individuals was estimated to be higher than those of the adults. $\mathrm{K}$ values varied between 1.1 and 1.3. No seasonal oscillation (as $\mathrm{C}=0$ no seasonality in the growth rate occurred and the growth did not stop at the winter point, WP) was observed in the estimation for the subadults. Winter point for the adult was October/November while the summer point (SP) was estimated to be April/May. In other words, the lowest growth occurred by October/November whereas at the time $\mathrm{SP}=0.4$ of the year, corresponding to April/May when the fraction of the year elapsed the growth rate was highest (Table 4). At $\mathrm{L}_{\infty}$ more than one cohort curve overlaps, indicating that growth in length ends at $5.7 \mathrm{~cm}$ (Fig. 6a). This was not the case for growth in shell width. 


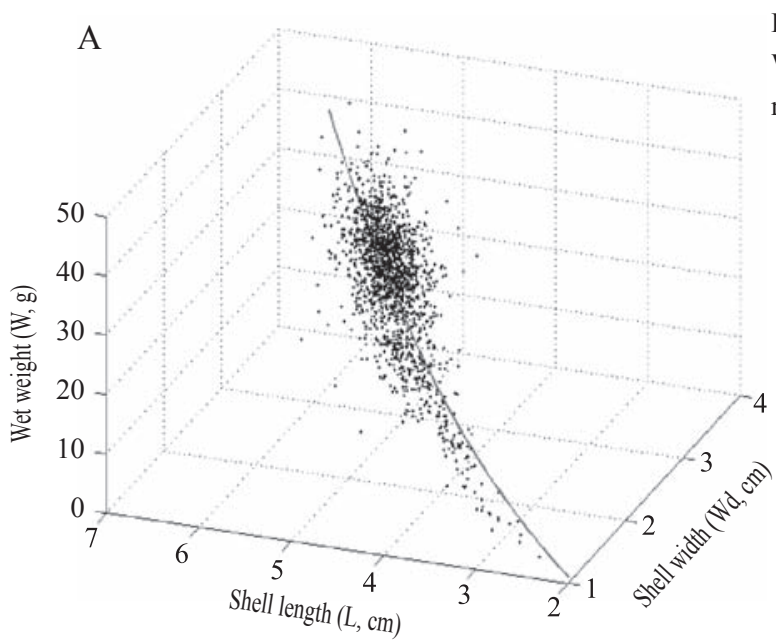

$\log _{10}\left(\mathrm{~W}_{5 \mathrm{~m}}\right)=0.482+1.768 \log _{10}(\mathrm{Wd})+1.423 \log _{10}(\mathrm{~L})$

$\mathrm{W}_{5 \mathrm{~m}}=0.329 * \mathrm{Wd}^{1.768 * \mathrm{~L}^{1.423}}$

$\mathrm{r}=0.92 \mathrm{p}=0.0000 \mathrm{n}=1545$

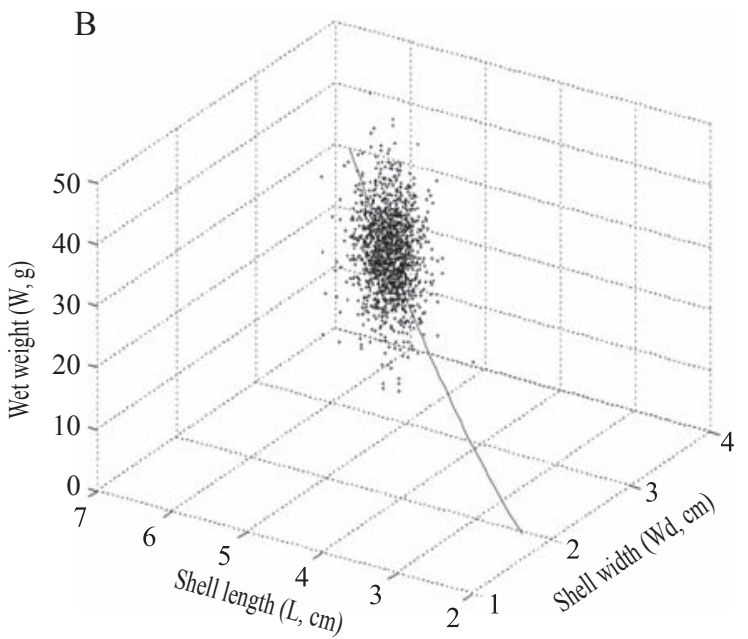

$\log _{10}\left(\mathrm{~W}_{10 \mathrm{~m}}\right)=0.036+1.070 \log _{10}(\mathrm{Wd})+1.211 \log _{10}(\mathrm{~L})$

$\mathrm{W}_{10 \mathrm{~m}}=1.085 * \mathrm{Wd}^{1.070 * \mathrm{~L}^{1.211}}$

$\mathrm{r}=0.69 \mathrm{p}=0.0000 \mathrm{n}=1395$

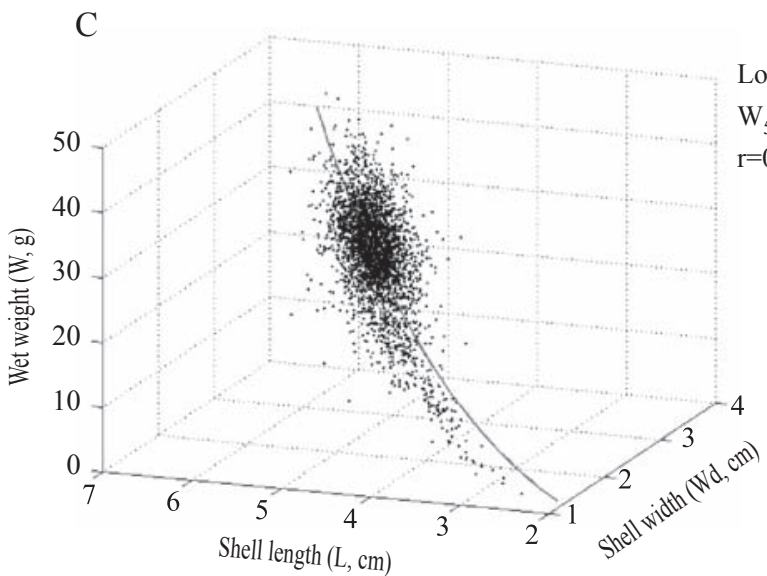

Fig. 5. Multiple-regression for length-width-wet weight of $C$. persicus individuals collected at $5 \mathrm{~m}$ (A), $10 \mathrm{~m}$ (B) and in the study area (C). 
TABLE 4

Growth parameters in shell length $(L)$ and width $(W d)$ of C. persicus collected within year 2001

\begin{tabular}{|c|c|c|c|c|c|c|}
\hline Stage & $\begin{array}{l}\mathrm{L}_{\infty} \\
(\mathrm{cm})\end{array}$ & $\begin{array}{c}\mathrm{K} \\
\left(\text { year }^{-1}\right)\end{array}$ & $\mathrm{C}$ & $\begin{array}{c}\text { WP } \\
\text { (year) }\end{array}$ & $\begin{array}{c}\mathrm{SP} \\
\text { (year) }\end{array}$ & $\begin{array}{c}\text { Score } \\
\text { (ESP/ASP) }\end{array}$ \\
\hline Subadult & 6.0 & 1.3 & 0 & 0 & - & 0.518 \\
\hline Adult & 5.7 & 1.1 & 0.7 & 0.9 (Oct/Nov) & 0.4 (Apr/May) & 0.754 \\
\hline All & 5.7 & 1.2 & 0.9 & 0.9 (Oct/Nov) & 0.4 (Apr/May) & 0.667 \\
\hline Stage & $\begin{array}{l}\mathrm{Wd}_{\infty} \\
(\mathrm{cm})\end{array}$ & $\begin{array}{c}\mathrm{K} \\
\left(\text { year-1) }^{-1}\right)\end{array}$ & $\mathrm{C}$ & $\begin{array}{c}\text { WP } \\
\text { (year) }\end{array}$ & $\begin{array}{c}\mathrm{SP} \\
\text { (year) }\end{array}$ & $\begin{array}{c}\text { Score } \\
\text { (ESP/ASP) }\end{array}$ \\
\hline Subadult & 4.0 & 1.1 & 0 & 0 & - & 0.366 \\
\hline Adult & 4.0 & 1.0 & 0.4 & 0.8 (Sep/Oct) & 0.3 (Mar/Apr) & 0.162 \\
\hline All & 4.1 & 1.1 & 0.2 & 0.8 (Sep/Oct) & 0.3 (Mar/Apr) & 0.160 \\
\hline
\end{tabular}

$\mathrm{L}_{\infty}$ : asymptotic length,

$\mathrm{Wd}_{\infty}$ : asymptotic width,

$\mathrm{K}$ : annual growth rate,

C: amplitude of seasonal growth oscillation,

WP: winter point,

SP: summer point,

ESP: Explained Sum of Peaks,

ASP: Available Sum of Peaks.

Asymptotic shell widths $\left(\mathrm{Wd}_{\infty}\right)$ were estimated to be 4.0 and $4.1 \mathrm{~cm}$ whereas $\mathrm{K}$ values were 1.1 and 1.0 for the subadults and adults, respectively. $\mathrm{C}$ values estimated for the width were lower than $C$ values for the length of the adults and all specimens. Shell width of the subadults showed a linear growth differential $(\Delta \mathrm{Wd} / \Delta \mathrm{t})$ as well as the length (Table 4$)$. This implies that the subadults grew within a von Bertalanffy growth curve. Cohorts of the big length overlapped at $\mathrm{L}_{\infty}$ points whereas there were three clear cohorts of the width (Fig. 6). Months when the highest $\mathrm{K}$ value was estimated were March/April. Comparisons of the growth constants between the length and width revealed that the shell width variable could be applied to ELEFAN I for estimates of the growth constants. This occurred because the observed maximum width $(4.0 \mathrm{~cm})$ was less than estimated $\mathrm{Wd}_{\infty}$ and the maximum length $(6.1 \mathrm{~cm})$ was greater than the $\mathrm{L}_{\infty}$.
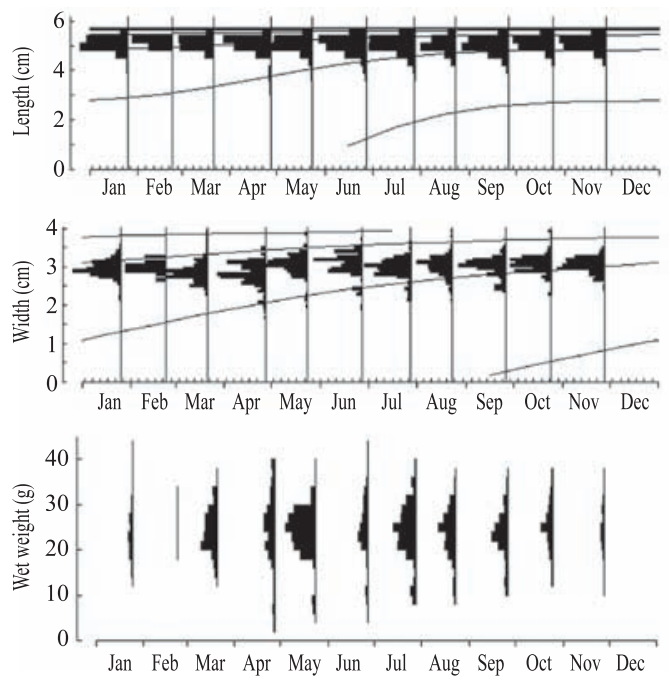

Fig. 6. Shell length (A), width (B) and wet weight-frequency distribution of $C$. persicus individuals collected in year 2001, which were applied to ELEFAN I to estimate growth constants of the species (Table 4). 
Annual production and mortality (estimates from method described by Holme and McIntyre (1971) estimates for C. persicus were $6.92 \mathrm{~g} \mathrm{~m}^{-2}$ and $2.57 \mathrm{~g} \mathrm{~m}^{-2}$ for the period JulyNovember 2000 and $7.86 \mathrm{~g} \mathrm{~m}^{-2}$ and $3.80 \mathrm{~g} \mathrm{~m}^{-2}$ for April-November 2001, respectively.

\section{DISCUSSION}

In the Mediterranean Sea, C. persicus, has an undervalued commercial value at present, unlike other Strombus species elsewhere.

Adults and yearlings of $C$. persicus were found between 1 and $12 \mathrm{~m}$ depths, on slightly gravelly sandy bottom (silt and clay not exceeding 4\%) whereas smaller individuals were observed grazing algae covering small rocks at depth shallower than $1 \mathrm{~m}$. The species was not recorded deeper than $10 \mathrm{~m}$ (Gucu et al. 2001) in skenderun Bay and vicinity of the study area, Turkey (Ergev 2002, Mutlu 2002), or $20 \mathrm{~m}$ off the Israeli coasts (Galil 2000). Shallow zones friendly to the life history of the conchs were characterized by lower loads of silt. Silt, negatively affects benthic recruits by clogging their gills or presenting unsuitable substrates for the microorganisms on which they feed (Peterson and Black 1988), and could also affect larvae prior to metamorphosis (Perez and Aranda 2000). Shallow zones were also typified by: clear water (Stoner et al. 1996), seagrass, meadows, rocky substrates covered by algae in intertidal zones that provide the nursery ground of subadults specimens (Stoner et al. 1996, Wiedemeyer 1998), and sandy bottoms suitable for burial of pre-yearlings and adults (Stoner and Sandt 1992, Anon 1999).

Intra-annual variation in density of C. persicus is likely due to physics (temperature and salinity) of the water column, particularly salinity due to variation of riverine inflows as a consequence of rainfall. Surface salinity $<38$ psu could affect regularity and periodicity of the $C$. persicus density in contrast to salinities near 39 psu between September 2000November 2001. The density of $C$. persicus was negatively correlated with water density at
5 m (Spearman, $\mathrm{r}=-0.46,-0.50, \mathrm{n}=25, \mathrm{p}<0.05$ ) while it was positively correlated with near bottom temperature at $10 \mathrm{~m}$ (Spearman, $\mathrm{r}=0.41$, $0.42, \mathrm{n}=25, \mathrm{p}<0.05)$. The temperature mostly affected growth and aging in size, spawning, recruitment and movement to suitable habitat, sheltering in aggregations around rocks, and winter burial or spring emergences of the species. Seasonal and monthly variation in density of $C$. persicus appeared to be controlled by the water temperature. During April-May, the population peak at $5 \mathrm{~m}$ shifted to $10 \mathrm{~m}$ depth, and again the population moved from $10 \mathrm{~m}$ to 5 $\mathrm{m}$ within 15 days (September 27-October 12, 2000). Similar movements occurred in spring (2001), but deepened instead of shoaled within a longer period (2 months). Seasonality and movement (between-depth counters and winter burial) of Strombus species were observed in association with bottom water temperature, which affects ontogenetic migrations performed for reproduction, feeding, high survival rate, avoidance of predation and effects of wave surge reported for different species of Strombus in the other seas and oceans (Stoner and Sandt 1992, Reed 1995, Manzano et al. 1998, Anon 1999).

Sex ratio of $C$. persicus was $60-57 \%$ (female): $40-43 \%$ (male). Intra-specific difference in sex ratio could be due presumably to mating during the coupling. For instance, females of species whose sex ratio of male:female is $>1$ are mated with two males (Wiedemeyer 1998, Mora and Mena 1998).

The shell width of $C$. persicus increased isometrically with shell length (Regression analysis, b: $1.035 \pm 0.014$ with a log-intercept $=-0.489 \pm 0.028$ ) and the relationship was statistically significant $\left(\mathrm{t}_{(3641)}=73.14\right.$, $\mathrm{p}=0.000$ ). All specimens showed cubic relationships between shell weight and length and the relationship was a positive allometry (Regression analysis, b: $3.317 \pm 0.441$ with a $\log$-intercept $=-0.985 \pm 0.028$ ) and the relationship was statistically significant (t-student test, $\left.\mathrm{t}_{(2938)}=81.614, \mathrm{p}=0.000\right)$. Relationships between shell weight and width was cubic with a negative allometry (Regression analysis, b: 
$2.560 \pm 0.013$ with a log-intercept $=0.173 \pm 0.013$ ) and the relationship was statistically significant ( $\mathrm{t}$-student test, $\mathrm{t}_{(2938)}=90.120, \mathrm{p}=0.000$ ).

Tissue weight of female comprised 16-17\% of total weight and $18 \%$ of male of C. persicus. Shell of Strombus galeatus (Swainson, 1823) represented $80 \%$ of total fresh weight (Mora 1998). In terms of shell growth in size (shell length and width), the life history was divided into two stages; subadults and adult. Growth of the subadults best fit to von Bertalanffy's growth model while adults required a seasonalized von Bertalanffy growth model as the growth in shell length increases at time of sexual maturity and shell enlarges in width and shell thickness as a function of shell lip thickness. Similar models have been noted earlier for queen conch (Appeldoorn 1998, Perez and Aranda 2000), S. luhuanus (Linnaeus, 1758) (Catterall 2001), and S. galeatus (Mora 1998).

\section{ACKNOWLEDGMENTS}

The present study was carried out within framework of a project ("Seasonal distribution of macrobenthos in coastal region (ErdemliKumkuyu) of Levantine Basin in Mediterranean Sea". Project code: YDABCAG-100Y015) funded by the Scientific and Technical Research Council of Turkey (TUBITAK). Rainfall data were obtained from the Local Meteorological Station in Erdemli, (Turkey). I thank also Karen Fisher for her valuable comments and correction of English of the text.

\section{RESUMEN}

El gastrópodo tropical Conomurex persicurs, ha sido introducido a una región subtropical, el noreste del Mar Mediterráneo, y ha invadido los fondos arenosos en un rango de profundidad de 1 a $10 \mathrm{~m}$. Se estudiarion las dinámicas poblacionales a partir de especímenes recolectados mediante un dragado estándard $(60 \times 15 \mathrm{~cm}$ de apertura de entrada y $0.5 \times 0.5 \mathrm{~cm}$ de tramado). Muestras de $C$. persicus fueron recolectadas mensualmente a produndidades de 5 y $10 \mathrm{~m}$ en las cercanías de Erdemil, Mersin, Turkey, en los meses de febrero y mayo del año 2000. La densidad dentro de un mismo año depende de los niveles de salinidad, mientras que al comparar años distintos está correlacionada con la temperatura del agua.

Palabras clave: Gastrópodos, distribución, ecología, dinámica de población, Mar Mediterráneo.

\section{REFERENCES}

Anonymous. 1991. Lecture notes prepared for the training workshop on the statistical treatment and interpretation of marine community data. FAO/IOC/UNEP Training Workshop, Alexandria, Egypt. 196 p.

Appeldoorn, R.S. 1988. Age determination, growth, mortality and age of first reproduction in adult queen conch, Strombus gigas, off Puerto Rico. Fish. Res. 6: 363-378.

Catterall, C.P., I.R. Poiner \& C.J. O’Brien. 2001. Long-term population dynamics of a coral reef gastropod and responses to disturbance. Austral. Ecology 26: 604-617.

Ergev, M.B. 2002. A baseline study for determination of macrobenthic epi/infaunal species in the northeastern Mediterranean. MaSc. Thesis, Institute of Marine Sciences, Middle East Technical University, Mersin, Turkey, $345 \mathrm{p}$.

Galil, B.S. 2000. The sea under siege-alien species in the Mediterranean. Biol. Invasions. 2: 177-186.

Gayanilo, F.C. \& D. Pauly. 2001. FAO-ICLARM fish Stock Assessment Tools (FISAT II ver. 0.4.1), FAO, Rome.

Gofas, S. \& A. Zenetos 2003. Exotic molluscs in the Mediterranean basin: Current status and perspectives, Oceanogr. Mar. Biol. 41: 237-277.

Gucu, A.C., Z. Uysal, E. Mutlu, A. Kideys., S. Tugrul \& F. Bingel. 2001. Identification of marine fauna and flora of a petroleum terminal in the skenderun Bay. Middle East Technical University, Institute of Marine Sciences, Erdemli, Mersin, Turkey. 49 p.

Holme, N.A. \& A.D. McIntyre. 1971. Methods for the study of Marine Benthos, Blackwell Scientific, Oxford, United Kingdom. 137 p.

Manzano, N.B., R.A. Aranda \& T. Brule. 1998. Effects of photoperiod on development, growth and survival of larvae of the fighting conch Strombus pugilis in the laboratory. Aquaculture 167: 27-34.

Mora, D.A. \& L. Mena. 1998. Population structure of the conch Strombus galeatus (Gastropoda : Strombidae) at Cabo Blanco, Costa Rica. Rev. Biol. Trop. 46: 37-46.

Mora, D.A. 1998. Growth and reproduction of Strombus galeatus (Gastropoda: Stombidae) along the Pacific coast of Costa Rica. Rev. Biol. Trop. 46: 27-36. 
Mutlu, E. 2002. Seasonal distribution of macrobenthos in coastal region (Erdemli-Kumkuyu) of Levantine Basin in Mediterranean Sea. (In Turkish: Akdeniz Levantine havzasinda bir kıyı bölgesinin (Erdemli-Kumkuyu) dip organizmalarının mevsimsel daılımları). Project no: YDABCAG 100Y015, TUBITAK (Scientific and Technical Research Council of Turkey), Final report, Ankara, Turkey. 123 p.

Mutlu, E. 2004. Sexual dimorphisms in radula of Conomurex persicus (Gastropoda: Strombidae) in the Mediterranean Sea. Mar. Biol. 145: 693-698.

Nicolay, K. \& E.R. Manoja. 1983. Strombus (Conomurex) decorus raybaudii $\mathrm{n}$. spp. La Conchiglia-The Shell. 176-177: 17-18.

Perez, M.P. \& D.A. Aranda. 2000. Distribution, abundance, density and morphometry of Strombus gigas (Mesogasteropoda: Strombidae) in Alacranes reef, Yucatan, Mexico. Rev. Biol. Trop. 48: 51-57.

Peterson, C.H. \& R. Black 1988. Density-dependent mortality caused by physical stress interacting with biotic history. Am. Nat. 131: 257-270.

Reed, S.E. 1995. Reproductive seasonality, periodicity, and associated behavior in a colony of Strombus pugilis (Mollusca, Gastropoda) in Peurto-Rico. Am. Malacol. Bull. 11: 117-121.
Stoner, A.W. \& V.J. Sandt. 1992. Population structure, seasonal movements and feeding of queen conch, Stombus gigas, in deep-water habitats of the Bahamas. Bull. Mar. Sci. 51: 287-300.

Stoner, A.W., P.A. Pitts \& R.A. Armstrong. 1996. Interaction of physical and biological factors in the large-scale distribution of juvenile queen conch in seagrass meadows. Bull. Mar. Sci. 58: 217-233.

Wiedemeyer, W.L. 1998. Contributions to the larval biology of the red-lipped conch, Strombus luhuanus L 1758, with respect to seed production for mariculture. Aquac. Res. 29: 1-7.

\section{INTERNET REFERENCES}

Anonymous. 1999. Report on queen conch stock assessment and management workshop, (Belize City, Belize, 15-22. March 1999, CFMC CFRAMP). pp. 105 (Downloaded: August 1, 2003, http://www. strombusgigas.com/BelizeConchWGReportFinal. PDF).

CIESM. International Commission for the Scientific Exploration of the Mediterranean Sea, http://www. ciesm.org, http://www.ciesm.org/atlas/index.html. 
